\title{
The Petroleum Systems from the Western Black Sea Basin, Romania
}

\author{
Ioana-Cornelia Mitrea (Rosu) $)^{1, *}$ Valentin-Mihail Batistatu ${ }^{1}$ and Ionut Lungu ${ }^{1}$ \\ ${ }^{1}$ Universitatea Petrol-Gaze din Ploieşti, Bd. Bucureşti nr.39, 100680, Ploieşti, Romania
}

\begin{abstract}
Although oil production has a long history in Romania, the offshore discoveries from the Western part of the Black Sea are still relatively newly developed and with further potential to be revealed. To find the best places for new wells, as well as making new oil field discoveries, it is very important to understand the petroleum system of the area. If the elements of the petroleum system are well understood, then the potential of the Black Sea will become bigger, as the complexity of the area will be acknowledged. Two major petroleum systems were discovered in the area, the thermogenic system, and the biogenic system. The thermogenic system is corresponding to the shallow area of the Black Sea, where current productive fields are, while the biogenic system is corresponding to the deeper area, currently being in the exploration stage. The purpose of this article is to present both petroleum systems from the Black Sea Romania, their elements, the evolution they had, and the major differences between the two.
\end{abstract}

\section{Introduction}

With the growth of demand on the oil market, the big companies started to search for additional resources and to develop new technologies for oil extraction. The first big step was to move from onshore oil discoveries to oil fields located offshore, initially in shallow water, and targeting deep water later on.

Romania is a country with rich oil history, starting in the middle of XIX century till today, having the first commercial well drilled close to Moinesti. Also, Romania was the pioneer in recording oil production of 275 tons in the international statistics, in 1987. Romania was followed by official oil production from other countries like United States, Canada or Russia. Some other remarkable aspects of Romania's oil history were the world's first refinery or the fact that Bucharest was the world's first city illuminated with kerosene [1].

Even though the oil industry started to develop in Romania quite early, the first discovery done in the Black Sea basin from offshore Romania was done in 1978. The Western basin of Black Sea is split into two main areas, the shallow water area and the deep watter zone. The shallow water area it is better understood and developed, having fields

* Corresponding author: ioana.cornelia_mitrea@yahoo.com 
with more than 20 years of production, while the area from the deep water is in the exploration phase, with new 3D seismic acquired and three new wells drilled in the last years. Each area has its petroleum system, and a clear understanding of it is important for the development of the reservoir and placement of new wells [2].

This paper presents the general geological settings of the Western Black Sea Basin, from the stratigraphic and tectonic points of view, the elements and definition of the petroleum systems in general, but also the two main petroleum systems from the studied area, the thermogenic system and the biogenic system.

\section{Black Sea Basin-General Overview and Geological Settings}

The Black Sea is a marginal basin with an area extend of about $432000 \mathrm{~km}^{2}$, lying between Asia and Europe. The water column stratification represents an unique characteristic of the basin, as a result of river input as well as basin topography. On the one hand the upper layer represented by the first 200meters is strongly oxygenized and has lower salinity (18PSU), on the other hand the lower one is anoxic and has a salinity that grows linearly with the water depth, from 19-20PSU to 22.5 PSU. In the lower water layer which is anoxic has been observed free hydrogen sulfide $\left(\mathrm{H}_{2} \mathrm{~S}\right)$ and because of it the benthonic life is absent and the organic matter is preserved [3].

The Black Sea can be split into two distinct depositional basins: the Western Black Sea and the Eastern Black Sea (Fig 1) separated by the Mid Black Sea High.

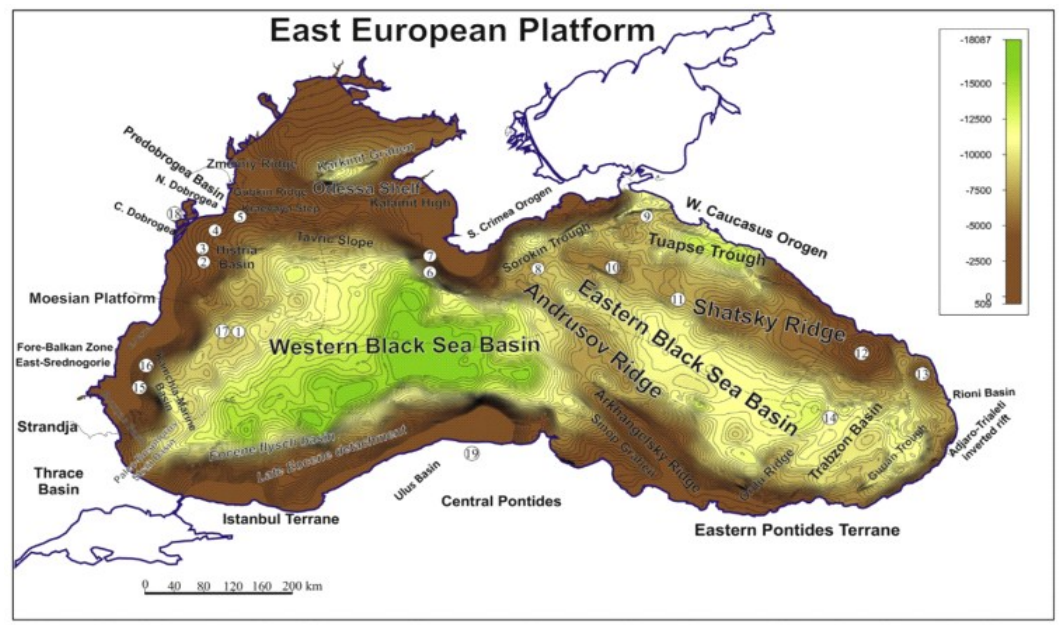

Fig. 1. Basement topography of the Black Sea basins (after Nikishin et al. 2015a, b) with key tectonic and depositional elements [4]

The two basins are having different characteristics, so the shelf from the Western part has a bigger areal extend, more than $180 \mathrm{~km}$ with gradients from 1:40 to 1:100, unlike the one from east which is only $20 \mathrm{~km}$ areal extend and a gradient of 1:40. Also the Easter part doesn't have the Piemont area, which is the transition zone between continental plato and abyssal plane, and which in the Western part is present and crossed by the Danubian alluvial cone. The abyssal plane which is found in both basins has the maximum depth of about $2212 \mathrm{~m}$ [5].

The main structural units that form the frame of the Black Sea basin are Moesian Platform, Balkan Orogeny, Pontic Mountains, East-European Platfrom, Crimeea and NorthDobrogean Orogeny. Out of all this, the main units that formed the Romanian part of the 
Western Black Sea Basin are: Meosian Platform, North-Dobrogean Orogheny and Scitian Platform, and the faults between them Intra-Moesian fault, Capidava-Ovidu fault, Peceneaga-Camena fault and Sfantu Gheorghe fault (Fig 2).

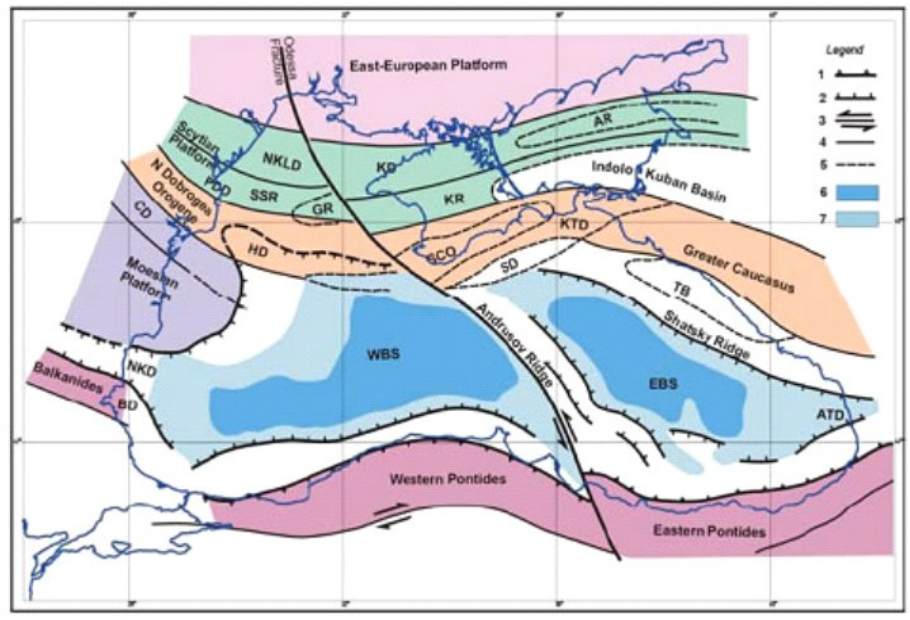

Fig. 2. Tectonic sketch of the Black Sea Region (after Dinu et al., 2003; Panin et al., 1994)[18]

From a tectonic point of view, the Black Sea basin represents a back-arc basin that opened during the Early Cretaceous-Early Paleogene northward subduction of the NeoThethus below the Balcanides-Pontides volcanic arc (Letouzey et al., 1977; Zonenshain and Le Pichon, 1986; Nikishin et al., 2001) [6].

The evolution of the basin is represented by extensional structures during AlbianCenomanian, followed by post-rift sedimentation and tectonic inversion from Upper Cretaceous and Paleogene. After these two main events, the succession was followed by gravitational sedimentation during Neogene, with thick sediments characteristic to deep water environment, and quiet tectonic evolution.

The first major event that happened during the evolution was the separation of the major plates (Moesic and Scytian), during the rifting Phase in Albian, This event had as results sediment collapse and normal fault appearance (Heraclea South fault and Peceneaga in the North), as well as horst-graben structures.

This is an area of subsidence where the accommodation space was created and favored the deposition of thick stacks of Paleogene sediments. During the Senonian, the western part of the Black Sea expanded, with rifting processes ceasing. Locally, there were reactivations of the previously formed faults, with a north-south orientation, in the Laramic tectonic activity (Upper Cretaceous-Lower Paleogene).

The second phase is corresponding to an inversion phase, that happened during Oligocene, when the sediments were compressed. This had as a result the conversion of the existing normal faults into reversed faults.

The stratigraphy that was intercepted along Romania offshore area can be grouped depending on the evolution stages of the basin. The oldest ones are prealpine structures, followed by extensional structures, structures deposited during inversion and gravitational Neogene structures.

The prealpine structures are the continuation of the existing tectonic units from the western margin of the Black Sea basin, having Jurasic and Triasic age.

The extensional structures developed while the basin was opening starting with Albian. and it is represented by micro-conglomerates, sandstones and limestones. If Lower Cretaceous has a limited areal extension, the Upper Cretaceous ones are having a wider 
distribution. The sediments from Senonian up to Eocene are showing deep water deposits, highlighting the gradual deepening of the basin. These are limestones, marls and calcareous sandstones (Fig.3).

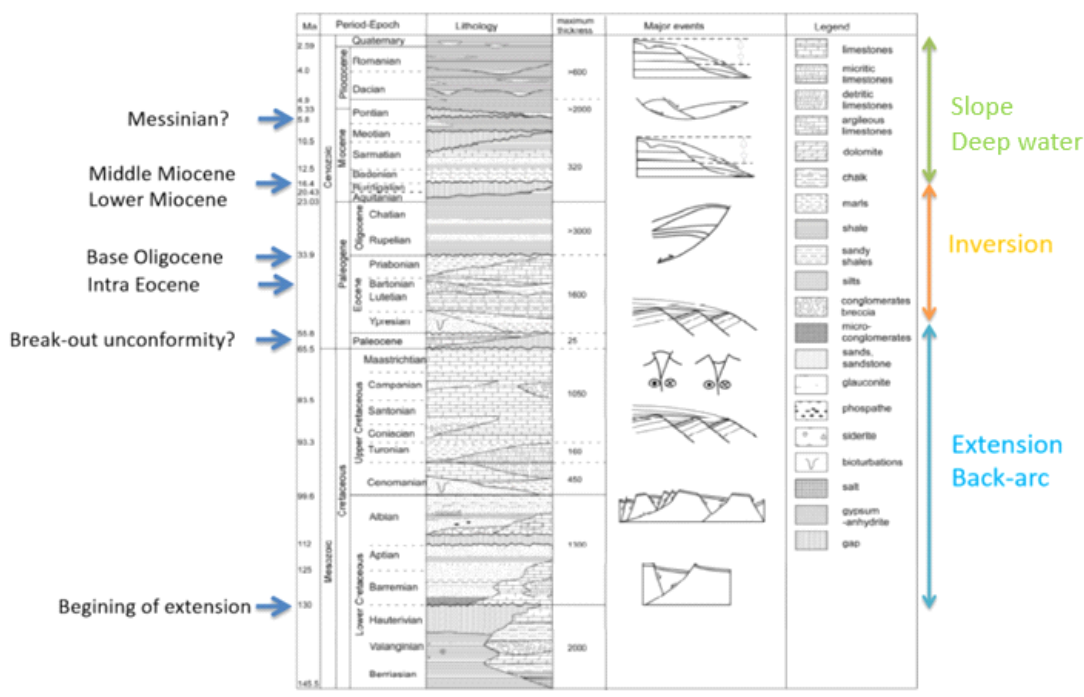

Fig. 3. Stratigraphy-the Central Romania offshore, Dinu et al., 2005; Munteanu et al., 2011; Tambrea, 2007 [7]

During the inversion period, the deep water deposits were interrupted by some sea level drops that created incised valleys, which were then filled in with shales.

Starting with the middle Miocene till the present days, Romanian self advanced into the basin, as a result of the large scale progradation. The specific for this timeline are slope deposits and deep water deposits, with shales and intercalation of sandstones or limestones for Paleogene and Neogene, and sand dominated deposits for Romanian to Quaternary deposits. Sometimes important orogeny, like the ones from the Carpathian evolution (Stiric and Valahian) had as consequences abrupt sea level drops and unconformities into the sediments from the Black Sea basin.

\section{Petroleum Systems}

The petroleum system concept was used for the first time in 1970 in Oklahoma, in a research laboratory, while making an exercise that had as aim the prediction of the places with a high probability of hydrocarbon storage. After that, scientists like Dow, Demaison or Meisser have a look into it, and then Magoon was the one establishing the definition and the elements of the petroleum system [8].

The petroleum system includes all the elements and processes that are essential if an oil and gas accumulation is to exist. The elements that are part of the petroleum system are source rock, seal rock, reservoir rock and trap. Besides the elements, also different processes are lead to the formation of a petroleum system. Those are generation, expulsion, migration, accumulation and preservation.

These essential elements and processes must be placed correctly in space and time, so that a petroleum accumulation can occur. That specific moment in time is called critical moment and it is the time that best depicts the generation-migration-accumulation of hydrocarbons in a petroleum system. All the elements of the petroleum system can be 
presented on a system event chart, which shows time in on axis, and the essential elements and processes on the other (Fig 4.).

\begin{tabular}{|c|c|c|c|c|c|c|c|c|c|}
\hline 400 & & \multicolumn{2}{|c|}{300} & \multicolumn{2}{|c|}{200} & \multicolumn{3}{|c|}{100} & \multirow{3}{*}{$\begin{array}{l}\text { Geologic Time } \\
\text { System Events }\end{array}$} \\
\hline \multicolumn{4}{|c|}{ PALEOZOIC } & \multicolumn{3}{|c|}{ MESOZOIC } & \multicolumn{2}{|c|}{ CENOZOIC } & \\
\hline D & $M$ & $\mathbb{P}$ & $P$ & 下 & $J$ & $\mathrm{k}$ & & $N$ & \\
\hline & & & & & & & & & Source Rock \\
\hline & & & & & & & & & Reservoir Rock \\
\hline & & & & & & & & & Seal Rock \\
\hline & & & & & & & & & Overburden Rock \\
\hline & & & & & & & & & Trap Formation \\
\hline & & & & & & & & & $\begin{array}{l}\text { Generation-Migration- } \\
\text { Accumulation }\end{array}$ \\
\hline & & & & & & & & & Preservation Time \\
\hline & & & & & & & & & Critical Moment \\
\hline
\end{tabular}

Fig. 4. System event chart, from Magoon and Dow,1994; courtesy of AAPG [9]

The source rock is a rock that can generate or has generated hydrocarbons that can migrate; it is considered the "kitchen" of a petroleum system. The source rock can be found in different stages, immature-when it was not matured enough, active source rock-when it is actively generating hydrocarbons, or oversaturated, when the rock has no more organic matter for oil and gas generation.

The source rock can be characterized by the quantity of organic matter, kerogen type and maturity degree. While the kerogen type and the quantity of organic matter depend on the depositional environment where the source rock was deposited, the maturity degree is determined by the tectonic events that affected the rock after its formation. Source rock can be shales or carbonatic rocks.

The reservoir rock is the rock that has storage capacity of accumulation and partial transfer of hydrocarbons. In order to do that the rock should have good porosity and permeability, in other works the rock should have interconnected pores that allow storage and flow of the fluids.

The reservoir rocks are mainly represented by sedimentary rocks. Sedimentary rocks can be split into two main categories, siliciclastic and carbonates. The siliciclastics are sands, sandstones and microconglomerate, and the most prolific reservoirs are the ones deposited in deltaic environment, channels and mouthbars, followed by shallow marine deposits, like barrier islands, beach ore shoreface deposits.

The carbonates are represented by fractured limestones and dolomites. The important characteristics of this type of reservoir are the lithofacies and the type of porosity. In carbonates, both primary and secondary porosity is playing a big role, and understanding how secondary porosity was developed is fundamental for the reservoir.

Rarely, magmatic and metamorphic rocks which were altered by different processes can form a significant system of fractures that allow the rock to store a significant amount of hydrocarbon.

The seal rock must be impermeable for oil and gas, and should be able to keep the oil into the reservoir rock. Most often shales and marls are acting as seals, but also tight compacted carbonatic rocks can play the same role. If for the detritic reservoir the seal most often associated is the shale, for carbonatic reservoirs, but not only, halite or anhydrite are representing the seal.

Another very important element for the petroleum system is represented by the trap. The trap is the structural, stratigraphic or lithological arrangement that allows the accumulation of the hydrocarbons and keeps them in a stable reservoir equilibrium.

Traps can be classified into three main categories

- Structural traps -formed as a result of tectonic events and are related to faults, folding or salt domes 
- Stratigraphic traps-formed due to lateral facies variation or unconformities

- Mixed traps- formed by the combination of tectonic and stratigraphic elements

When discussing petroleum system evolution, the first process is represented by the generation of hydrocarbons, a process that depends on the transformation suffered by the organic matter from the source rock. While it is buried the rock is affected by diagenesis, catagenesis and metagenesis.

After the generation, oil and gas start the migration, inside the source rock until the reservoir rock and inside it. Migration is influenced by chemical, physical and geological factors. Migration can be primary, secondary or tertiary. Primary migration takes place when oils is expelled from the source rock and start to travel until will reach the reservoir rock and it depends on compaction degree, temperature and capillary pressure. Secondary migration happens into the reservoir rock and it depends on the new pressure condition. This movement will be mainly laterally, on reservoir stratification, while the primary migration happens vertically. Tertiary migration could happen under the same condition as secondary migrations. Mud volcanoes are an example of tertiary migration, as a result of the accidental release of gas on fractures.

Accumulation of oil and gas will happen only if certain conditions are met, reservoir rock sealed by an impermeable layer arranged in a trap that will not allow hydrocarbons to further migrate.

The last process that could affect a petroleum system is represented by degradation. During this phase natural or artificial elements, like orogenic movement, bacteria or wells, affect the equilibrium of the reservoirs

While discussing the petroleum systems from Romania, two main systems can be identified, biogenic and thermogenic. Black Sea basin is one of the areas where both can be observed and described (Fig.5).

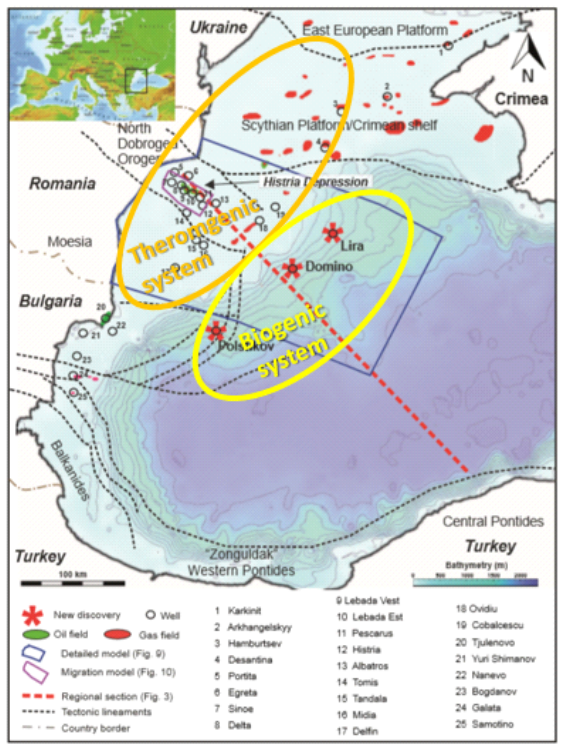

Fig. 5. Sea-floor map of the Western Black Sea sub-basin showing regional tectonic units and lineaments, and the location of oil- and gas fields and discoveries offshore Romania and Bulgaria. and the characteristic petroleum system [10]

The thermogenic system is the one responsible for the fields which are in the exploitation phase and are placed in the shelf area of the Black Sea basin. If in the beginning, the focus was on the shallow water, when exploration focus was oriented into 
the deep water zone, the biogenic system was discovered and high amounts of gas were highlighted.

\subsection{Thermogenic System of Black Sea}

When we describe a petroleum system it is important to understand all the elements as well as the condition in which the system it is formed. During its evolution, the Black Sea basin went through different stages, which played important roles in the petroleum system evolution.

In the post-rift period, because the basin was closed, water circulation was restricted and the water salinity was different on the vertical scale, due to the fresh water supply from the continent and the meteoric one. In this conditions the oxygen did not penetrate deep into the basin water and so an anoxic environment was formed, favorable for organic matter accumulation in the rock from the base of the basin. Into this condition, Mykrop Shales were deposited during Oligocene time; having a similar composition with the disodilic shales from the Carpathians, as the main sediment source from Black sea is the East European Platform.

This shales (Mykrop) are considered to be the main source rock for the thermogenic system. They have a TOC of about $0.90 \%$ and thickness that can reach $1500 \mathrm{~m}$. The hydrogen index has specific values for kerogen able to generate oil and gas, with a dominant component of vitrinite, but also a significant amount of sapropel. Characteristic for the marine depositional environment is also a high amount of dinoflagellate[11].

Different analysis were made on cores or cuttings of different ages from the Black sea basin, in order to identify the generation potential of the samples. The samples analyzed were Lower Cretaceous, Eocene and Oligocene, and some of the analysis done were RockEval pyrolysis, Vitrinite reflectance, gas-chromatography or organic petrographic analysis. From the Rock-Eval analysis parameters like TOC (Total Organic Content), HI (Hydrogen Index) and OI (Oleanan Index) were established. The vitrinite reflectance, color or fluorescence identification of the organic matter was established with the organic petrography analysis [10].

All the results were analyzed with special geochemical software, and some of the most representative graphs are presented below. The TOC graph (Fig. 6) shows how Oligocene age samples as most dominant in areas presented as good source rock.

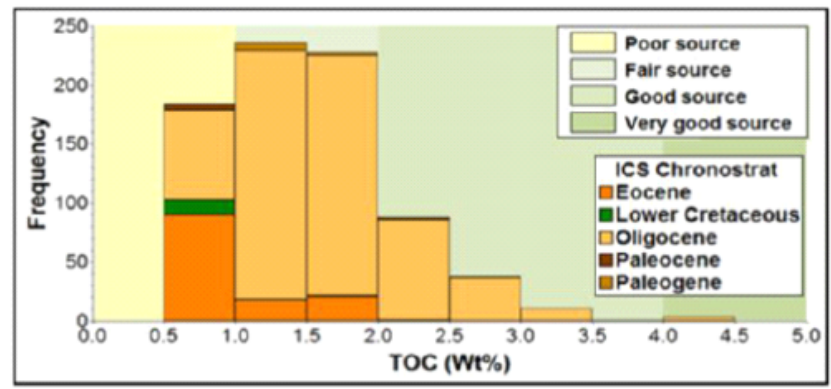

Fig. 6. Diagram showing the TOC content variation in the analyzed samples and their potential of hydrocarbon generation [10]

Also, the Vitrinite Reflection and kerogen type depending on the Hydrogen Index were plotted (Fig.7 and Fig.8). Those graphs show an immature TOC, or in the early to the mid mature stage, that has different HI values. 


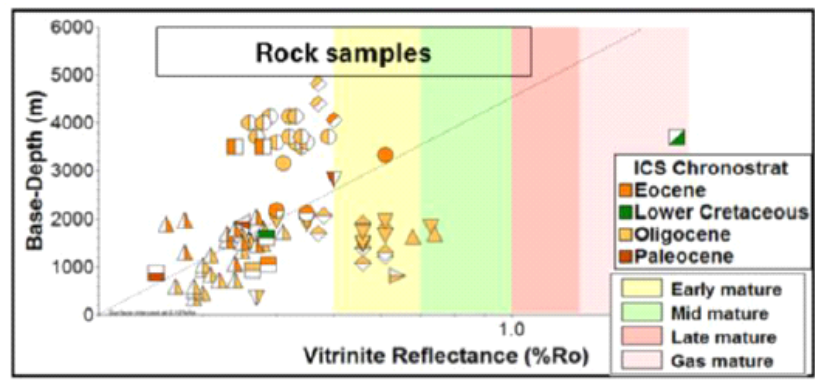

Fig.7. Vitrinite reflectance representation [10]
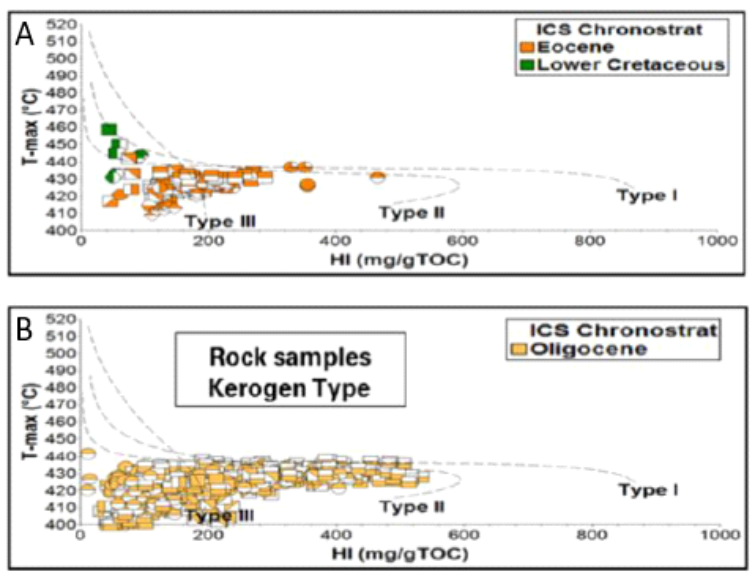

Fig. 8. Plot with Hydrogen Index and kerogen type corresponding to different age samples (ACretaceous \&i Eocene, B- Oligocene) [10]

The results showed the Cretaceous analyzed samples are having low HI, and low TOC $100 \mathrm{mg} / \mathrm{g}$, specific to a low potential of hydrocarbon generation, mainly gas, with kerogen type III/IV specific for the continental area. In the Eocene and Oligocene samples, the HI had bigger values, specific for marine kerogen type. The biggest HI value was recorded in the Mykrop shales, up to $600 \mathrm{mg} / \mathrm{g}$ TOC, with different types of kerogen, type II, type III and type I [13].

The reservoir rock for the thermogenic system is represented by different age types of rocks. The oldest ones are the Albian, mainly clastic sediments (sandstones, microconglomerates); then the Upper Cretaceous reservoir (Santonian-Coniacian-Turonian series) represented mainly by carbonatic deposits (limestones and sandstones with a high amount of carbonates), and the youngest reservoir represented by Eocene rocks, limestone, sandy marls and sandstones. As the reservoirs are split between limestone and detritic facies, also the porosity system expected is different. A complex matrix pore-system of micro-fractures, vugs, molds, inter-crystalline and inter-particle porosities are expected to hold the hydrocarbons for the limestone facies, while in the detritic facies are mainly intergranular porosity is expected to be dominant.

The seal rocks are also being different depending to one reservoir to another, and they are shales, marls or tight limestone that overlap the hydrocarbon bearing formations. One example could be the Oligocene shales that are acting as seals for the Eocene reservoirs.

Due to the complex processes that affected the basin formation also the trap was formed as a result of combined processes. Traps are of a combined nature, structuralstratigraphic and lithologic (compaction, lateral facies changes). First, the rifting phase 
created horst and graben structures, then during inversion some faults were reactivated and anticline were formed.

During the Upper Cretaceous to Oligocene several unconformities affected the area, caused by eustatic sea-level changes whereby periodic exposure and erosion occurred-in the carbonate platform. These sea-level changes are more sensitive due to the low expected water depth and low inclination of the platform. At the end of the Eocene epoch, severe erosion took-place forming paleo-valleys on either side of the remnant high. Thick Oligocene shales in-filled the paleo-valleys and covered the structure forming a trap that now is defining the existing production fields.

As the source rock was deposited in the middle of the Black Sea basin, were the thickest sediment succession was deposited, at around $3000 \mathrm{~m}$ to $5000 \mathrm{~m}$, migration was done laterally in SE-NW direction. One of the studies conducted on this subject showed how the facies was looking at Oligocene time, and which migration pathway could have been used by the hydrocarbons (Fig.9.A and B).
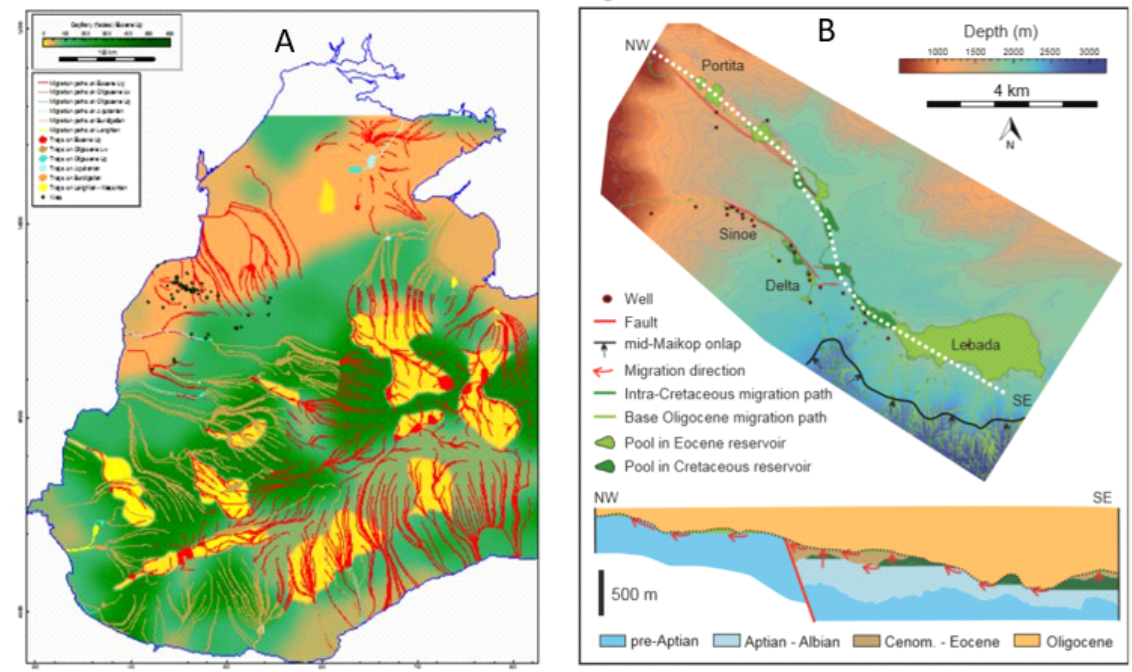

Fig. 9. Map with main migration pathways in Eocene-Lower Oligocene; B-Lateral migration model for Portița-Lebăda area [10]

On the map are represented the shales, the silts and sands, as well as the migration paths. Depending on the area where are placed, some of the shales are able to generate hydrocarbons, some others are immature and some others are overcooked. Fig B presents the migration pathway that was followed by the oil for the reservoirs from the thermogenic system. This pathway was represented mainly by the base Oligocene unconformity. Because the traps were not fully closed, hydrocarbons were filling the trap and then continue to migrate higher up on the structure. In order for the migration to take place, some conditions must be full field above the erosional surface must be an impermeable rock and right under the unconformity must be a porous-permeable layer. This rock would have been used as migration pathway in case the capillary pressure is smaller than on the unconformity. According to the overall understanding, the timing and migration started sometime in Pontian.

The summary of the thermogenic petroleum system can be summarized in the following diagram, inspired from Magoons articles and adapted to the basin (Fig 10). 


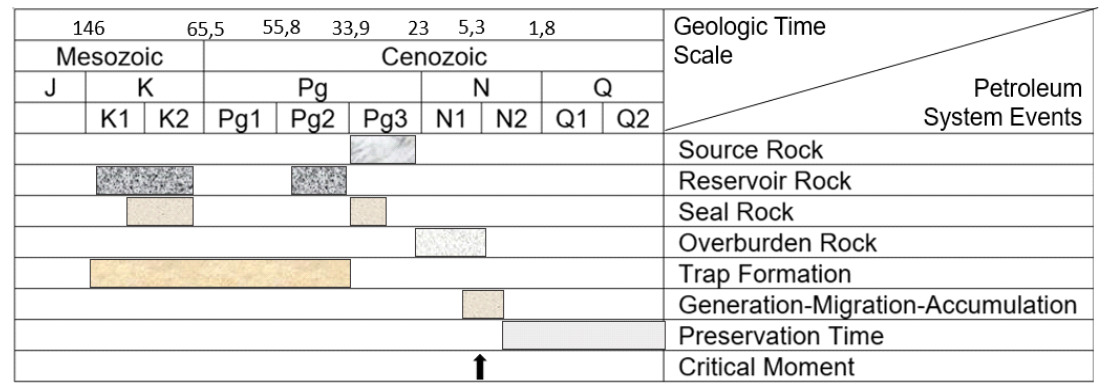

Fig. 10. Thermogenic petroleum system schematic for Western Black Sea Basin

The results of this thermogenic petroleum system have been seen in the Histria Depression area from the Western Black Sea basin, where the structural alignment Sinoe, Delta, Lebada West-Lebada East- Pescarus represents the active exploitations fields from off-shore Romania. These fields have different accumulations, oil, oil and gas and gas reservoir and have been producing from different periods, some from 1987(Lebada West), while others only from 2009 (Delta). In 2019 the offshore shallow marine oil and gas production was around 25.000 bep/day and was representing about 17\% of OMV Group in Romania.

\subsection{Biogenic system of Black Sea}

The biogenic system characteristic of offshore Romania was developed during a period of tectonic calm, with deep water deposits, that happened in the latest stage of basin evolution.

In order for a biogenic system to exist, anaerobic bacteria that can transform the organic matter into methane gas must be present in the system. This needs on the one hand a viral space filled with organic matter, which will serve as food for the bacteria, and on the other hand porous-permeable layers which will be able to store the methane gas resulted from the action of them.

Other characteristics of the biogenic system are the fact that methane is traveling on short distances until it finds a reservoir and that organic matter has a transformation rate of $100 \%$. Even though the organic matter accessed by the bacteria is totally transformed into methane, the bacteria can reach only a part of the shales.

Starting from Miocene the basin was developing as a deep water basin, with no major tectonic events. During basin history, rivers were bringing considerable amounts of sediments, from North-North-West, and siliciclastic sediments were being deposited above the existing lithologies. These newly deposited sediments were shales, silts, sand and sandstones (Fig.11).

The different sources of sedimentation have been also observed in the deep wells drilled on the structures, during Pontian times. The intercepted layers from these wells showed a lower sequence with more quartz-rich sand (Scythian input from North), while the upper ones have lithic-rich character specific to North Dobrogean-Meosian input from North-West. The change in sediment source direction came because of a considerable fall in the sea level. Another significant difference between the two is the sand/shale ratio that is significantly higher in the lower Pontian sequence [12]. 


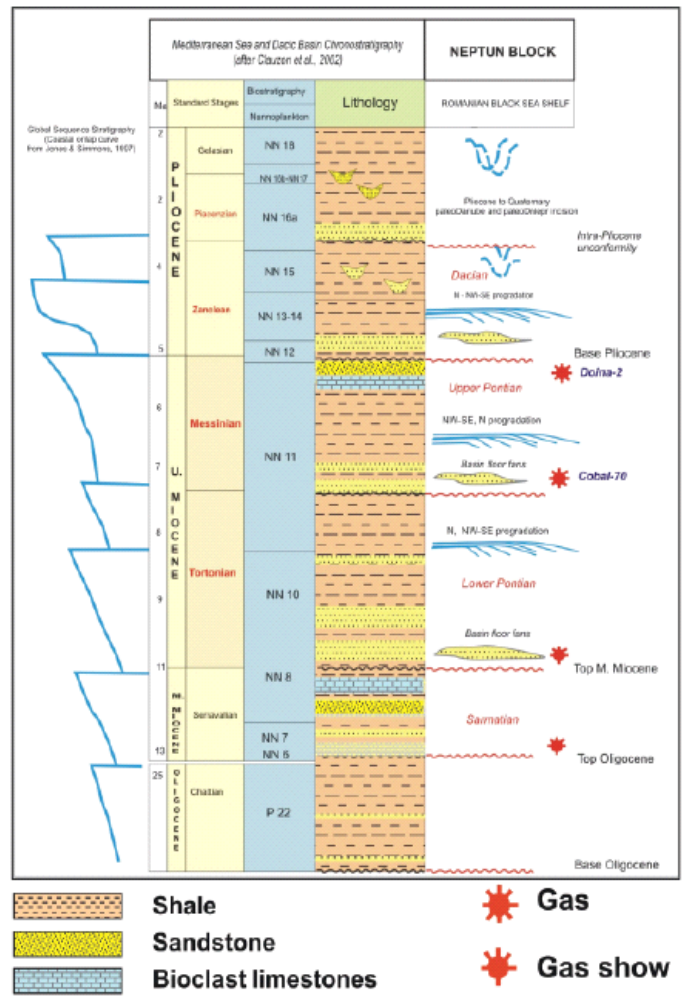

Fig. 11. General lithostratigraphy of off shore Romania correlated with Mediterranean stages [12]

The only tectonic events that affected the basin during the last phase of basin evolution was gravity driven tectonic on the existing detachment surfaces provided by the existing Oligocene shales. During this time the basin was affected by growth faults, rollover anticline and toe-thrust structures. The effect of the toe-thrust deformation can be seen up to Upper Pontian level.

While discussing the biogenic petroleum system, the source rock is represented by the mudstone from Pliocene (Pontian). For this the TOC is moderate $-0.66-0.67 \%$, and the HI shows kerogen specific for gas and the $S_{2}$ values show a moderate potential for hydrocarbon generation. Kerogen has as main components vitrinite and sapropel in low proportion, and the presence of $\mathrm{C}_{30}$ steran indicates a marine depositional environment. Because the rock is in an immature phase, with vitrine reflectance $<0.5 \%$, only biogenic gas can be generated [11].

The sands, sandstones and slits, having the same Pontian age, represent the reservoir rock. In addition, the seal rock is having same age, Pontian, and is covering the reservoir layers. Because the deep area is still under the exploitation phase, not too many details are known related to the properties of the reservoirs.

The traps observed on seismic and intercepted into some of the drilled exploration wells can be classified into two types, structural traps, combined with stratigraphic elements, like Doina well or Cobalcescu, but also mainly stratigraphic driven traps, the one from Domino well.

The main characteristic of the biogenic system for Black Sea Basin is the fact that all elements, source rock, seal and reservoir rock are having the same age, Pontian. The shales developed into the Pontian, with organic matter stored in it, are the source rock witch with 
bacterial help are generating biogenic gas. The resulted gas is traveling short distances to the closest stratigraphic trap with the same age, where is stored in new potential reservoirs.

As was mentioned the full picture understanding of the biogenic system is still in its initial stages. Seismic campaigns with 2D and 3D seismic acquisition were done, and based on it 5 wells were drilled by OMV in a joint venture with Exxon Mobile. Also Lukoil, together with Romgaz has leased a perimeter, in Neptun perimeter vicinity, where are making their own researches.

The diagram of the biogenic system can be seen in the figure below.

\begin{tabular}{|c|c|c|c|c|c|c|c|c|c|}
\hline \multicolumn{3}{|c|}{ Mesozoic } & \multicolumn{6}{|c|}{ Cenozoic } & \\
\hline \multirow[t]{2}{*}{$\mathrm{J}$} & \multicolumn{2}{|c|}{ K } & \multicolumn{3}{|c|}{$\mathrm{Pg}$} & \multicolumn{2}{|c|}{$\mathrm{N}$} & Q & \\
\hline & K1 & $\mathrm{K} 2$ & Pg1 & Pg2 & Pg3 & $\mathrm{N} 1$ & N2 & \begin{tabular}{l|l|} 
Q1 & Q2 \\
\end{tabular} & \\
\hline & & & & & & & & & Source Rock \\
\hline & & & & & & 38 & & & Reservoir Rock \\
\hline & & & & & & & & & Seal Rock \\
\hline & & & & & & & & & Overburden Rock \\
\hline & & & & & & D & & & Trap Formation \\
\hline & & & & & & & & & Generation-Migration-Accumulation \\
\hline & & & & & & & & & Preservation Time \\
\hline & & & & & & & I & & Critical Moment \\
\hline
\end{tabular}

Fig. 12. Biogenic petroleum system schematic for Western Black Sea Bas

\section{Comparison}

While discussing about the two main petroleum systems, several differences can be observed between the two:

- The origin of the hydrocarbon is different, the thermogenic one is coming as a result of several processes physical and chemical processes, while the gas accumulated from the biogenic petroleum system is the result of bacterial activities

- The type of hydrocarbon generated in the thermogenic system is oil with gas associated, for Lower and Upper Cretaceous reservoirs, and gas for Eocene, while the biogenic system has only gas reservoirs

- The source rock age is different in terms of TOC and HI content, but also by the age of deposition. The Mykrop shales, source rock for the thermogenic system are Oligocene age and are considered to be mature rocks able to generate oil and gas, as a result of the catagenesis processes that affected the rock. Unlike those, the Pontian shales are immature, affected only by diagenesis, with the only capability of generating biogenic gas.

- The age and composition of the reservoir rocks are different in both systems. If the older one has as reservoir rocks a combination of siltic and carbonatic rocks, with ages varying between Albian, Santonian-Turonian-Coniacian and Eocene, the younger one (Biogenic) has Pontian siliciclastic reservoirs. Also an important aspect is the fact that even though some of the reservoirs from the thermogenic system are having low permeabilities, the reservoirs are somewhere on the edge between conventional and unconventional reservoirs and have been producing after hydraulic fractures were performed.

- If reservoir rock and source rock are looked at together, also an important difference can be spotted. In the thermogenic petroleum system the source rock it is younger than the reservoir rock, while for the other system source and reservoir rock are having both the same age. 
- The migration pathway it is also different, for one of the system it is done mainly on the unconformity surfaces that lay on the base of the source rock, and it is longer. For the biogenic system the migration pathway is shorter and happens inside the source rock till the vicinity reservoir rocks.

- The traps are more affected by the tectonic events for the thermogenic system, because the traps started to form while de basin was opening and both rifting phase and inversion phase had an important role in trap definition. From the biogenic system traps are less affected by tectonic, as being developed in a calm deep water setting, influenced only sometimes by gravity tectonics.

- The deep of the water where reservoirs are placed for each petroleum system is different. For the thermogenic system, the reservoirs are placed in shallow waters, at about $50 \mathrm{~m}$ water depth, where drilling is quite well known from a technical perspective and, also costs are acceptable. Unlike this, the biogenic reservoirs are placed in deep water, around $1000 \mathrm{~m}$ water depth, with higher drilling risk and costs, moreover being the pioneers in deep water drilling in Western Black Sea Basin.

- Finally yet importantly there is the difference in the degree of understanding for each of the petroleum systems. The thermogenic system is known for about 50 years, when the first exploration wells were drilled, and it was confirmed and put into production for various fields in offshore Romania area. Data are coming from wells, cores, cuttings, 2D and 3D seismic, as well as production behavior for different years depending a one field to another. On the other hand, the biogenic system was under the radar for the last 10 years, when after the acquisition of 3D seismic for the area in 2009, and followed by the drilling of a limited number of exploration wells ( 5 by OMV Petrom), since 2012. This area is still into the exploration phase, and even though some of the wells had positive results and approximate evaluation of in place were given by the company, there is still a long way to go until the area will be fully and correctly understood and put in production.

\section{Conclusion}

Although Romania it is a country with rich oil history, the Wester Black Sea basin is a relatively new area for Romanian exploitation and exploration. The first well drilled in shallow water that proved oil was done in 1978, while the first successfully drilled well in deep water was in 2012.

From a geological point of view, the basin started to develop as a rift area in Albian/Aptian and was converted in inversion during Pleogene. Starting with Cenozoic the basin had deep water deposits, having only gravity tectonics affecting the sediments. During the entire evolution of the basin, several sea-level drops happened, which had as result different unconformities with high importance.

The sedimentary stack of rocks has at the base the Neocomian shales, followed by Cretaceous deposits with sandstones and limestones, then Eocene Limestones, Oligocene shales and sand and shale intercalation for Miocene, Pliocene and quaternary deposits.

When a basin is analyzed it is really important to understand the petroleum system or systems. The petroleum system represents all the elements and processes that are essential if an oil and gas accumulation is to exist. So, the first element that should exist in order to generate hydrocarbon is represented by the source rock, which is a rock with high organic content, able to expel oil or gas after the organic matter was "cooked". Secondly, a reservoir rock, with good storage capacity (porosity and permeability) is needed, and also a seal rock that could prevent further migration of hydrocarbon. Last, but not least all rocks should form the structural arrangement able to store and keep the hydrocarbons, named trap. The main processes that happened in one petroleum system are the generation of the hydrocarbon, followed by migration and in the end preservation. Timing is also an 
important part, because critical moment defines the time when the oil accumulation can appear.

Inside the Wester Black Sea basin, two main petroleum systems were defined, with significant differences between them. The first one is considered the thermogeic system and it is located in shallow water. This is represented by Oligocene shales source rock, which generated oil and gas, which were stored into Albian, Santonian-Coniacian-Turonian and Eocene reservoirs. The traps are a mixture of structural and straigraphic elements, being mainly anticlines affected by faults and/or by erosional surfaces. A distinct characteristic of this system is the fact that the source rock is younger than the reservoir rocks. The migration pathway was the base of Oligocene shales, on the unconformity, which facilitated the storage of the reservoirs placed immediately under it.

The thermogenic petroleum system is been produced in the Black Sea basin since 1987- with Lebada West and Lebada East fields, and several others were discovered and put into production during the time ( Sinoe-1978, Pescarus-2000 and Delta-2009). This system is well understood due to a big number of wells drilled, cores acquired, different analysis done on rock samples as well as $2 \mathrm{D}, 3 \mathrm{D}$ seismic and production data.

The biogenic system is the second system from the Black Sea basin and it is quite different from the thermoenic one. The hydrocarbons (gas) are produced by the bacterial that are consuming the organic matter and are traveling on short distances on the stratigraphic traps formed in the same time. All elements of the petroleum system are having the same age, Pontian. This system is less known than the thermogenic one, here 2D and 3D seismic were acquired and few exploration wells were drilled from 2012 till today. Big companies are spending money and effort in order to understand how this system is developing so that they can convert it from an exploration play into a productive one.

The proper understanding of a petroleum system is very important from an oil production perspective. Knowing how the oil was formed and where it was stored, it is important not only for the fields already in production and for finding the best spots for new well locations, but also for the exploration phase. In the exploration phase understanding the petroleum system will help to find new reservoirs, by pointing to the most favorable area were traps could have been formed and migration could have filled it.

\section{References}

1. https://www.historia.ro/sectiune/general/articol/evolutia-industriei-petroliereromanesti-in-perioada-1857-1945

2. R. Cataraiani, E. Tudora, B. Dzhaikiev, S. K. Subbiah, O. M. Nohut, JPT, Multidiscipline Approach, Advanced LWD Boost Multistage Fracturing in Romania (2011)

3. M.M. Candea, A-M. Gheorghe, A. Paiu, M. Paiu, Va supravietui caracterul unic al ecosistemului Marii Negre schimbarilor climatice? (2018)

4. M.D Simmsons., G. Tari, A.Okay, Petroleum geology of the Black Sea: introduction, Geological Society, 18 (2018)

5. https://en.wikipedia.org/wiki/Black_Sea

6. G. Tari, J. Davies, R. Dellmour, E. Larrtt, B. Novotny, E. Kozhuharov, The Leading Edge-Special Section Black Sea Play types and hydrocarbon potential of the deepwater Black Sea, NE Bulgaria, 1076 (2019)

7. I. Munteanu, C. Dinu, AAPG, Tectonics of the Western Black Sea back-arc basin as reveled by the architecture of its sedimentary fill (2018)

8. L.B Magoon and W.G. Down, AAPG memoir 60, The Petroleum System-from source to trap (1994)

9. L.B Magoon and E Beaumont, Petroleum system, 3 
10. R. Olaru-Florea, C. Ungureanu, C. Krezsek, Journal of Petroleum Geology, 3D basin modelingog Oligocene-Miocene Maikop source rock offshore Romania and in the Western Black Sea (2018)

11. G. Georgiev, Turkish Journal of Earth Sciences, Geology and Hydrocarbon Systems in the Western Black Sea, 21, 723 (2012)

12. Z. Bega, G. Ionescu, The Leading Edge, Neogene structural styles of the NW Black Sea region, offshore, 1082 (2009)

13. N. Anastasiu, Hidrocarburile din Marea Neagra, intre provocari si riscusi (2019)

14. V. M Batistatu., Analiza cantitativă a bazinelor sedimenatre, Editura Universităţii din Ploieşti (2000)

15. C. Krezsek, R. Bercea, A. Seghedi,G. Tari, AAPG Field Trip Guide, Cretaceous Depositional Systems and Tectonic Evolution of the Romanian Black Sea (2016)

16. C. Krezsek, R. Bercea, G Tari, G. Ionsecu, Geological Society, London, Special Publications, Cretaceous sedimentation along the Romanian margin of the Black Sea: inferences from onshore to offshore correlations, Petroleum Geology of the Black Sea (2017)

17. L.B. Magoon and J.W. Schmoker, U.S. Geological Survey World Petroleum Assessment, The total petroleum system-the natural fluid network that constrains the assessment unit (2000)

18. I. Moroșanu, Romanian Journal of Earth Sciences, The hydrocarbon potential of the Romanian Black Sea continental plateau, 86, 91 (2012)

19. I. Munteanu, L. Matenco, C. Dinu, and S. Cloetingh Kinematics of back-arc inversion of the Western Black Sea Basin TECTONICS, 30 (2011)

20. N. Panin, C. Strechie, A Journal of Archaeomythologt, Late Quaternary Sea-level and Environmental Changes in the Black Sea: Brief Review of Published Data (2006)

21. G. Tari, C. Menlikli, S. Derman, AAPG Conference, Kiev, Deepwater play types of the Black Sea: a brief overview, (2010)

22. https://oiljournal.info/en/content/nv/336/the-power-of-high-tech-unlocking-the-blacksea-s-potential/

23. https://ihsmarkit.com/research-analysis/ep-activity-in-the-romanian-and-bulgarianwaters-of-the-black-sea-where-do-we-go-from-here.html

24. http://archive.iwlearn.net/bsepr.org/Text/ESP/GeologyArchaeology.htm 